IZA DP No. 7518

Bridging the Gap in Pension Participation: How Much Can Universal Tax-Deferred Pension Coverage Hope to Achieve?

Nadia S. Karamcheva

Geoffrey Sanzenbacher

July 2013 


\title{
Bridging the Gap in Pension Participation: How Much Can Universal Tax-Deferred Pension Coverage Hope to Achieve?
}

\author{
Nadia S. Karamcheva \\ Urban Institute and IZA \\ Geoffrey Sanzenbacher \\ Analysis Group and Boston College
}

Discussion Paper No. 7518

July 2013

IZA

P.O. Box 7240

53072 Bonn

Germany

Phone: +49-228-3894-0

Fax: +49-228-3894-180

E-mail: iza@iza.org

Any opinions expressed here are those of the author(s) and not those of IZA. Research published in this series may include views on policy, but the institute itself takes no institutional policy positions. The IZA research network is committed to the IZA Guiding Principles of Research Integrity.

The Institute for the Study of Labor (IZA) in Bonn is a local and virtual international research center and a place of communication between science, politics and business. IZA is an independent nonprofit organization supported by Deutsche Post Foundation. The center is associated with the University of Bonn and offers a stimulating research environment through its international network, workshops and conferences, data service, project support, research visits and doctoral program. IZA engages in (i) original and internationally competitive research in all fields of labor economics, (ii) development of policy concepts, and (iii) dissemination of research results and concepts to the interested public.

IZA Discussion Papers often represent preliminary work and are circulated to encourage discussion. Citation of such a paper should account for its provisional character. A revised version may be available directly from the author. 


\section{ABSTRACT}

\section{Bridging the Gap in Pension Participation: How Much Can Universal Tax-Deferred Pension Coverage Hope to Achieve?*}

In light of the declining pension coverage of low-income workers, policy makers have discussed requiring all employers to offer individual retirement accounts, similar to defined contribution plans. How likely to participate are workers who currently do not have access to a pension plan? We address this question by using plausibly exogenous variation in pensionplan availability to estimate the determinants of participation in a standard selection on unobservables model. We find that currently uncovered low-income workers are fairly likely to participate in a newly offered plan, yet they are much less likely to do so than currently covered workers.

JEL Classification: J08, J26, J32

Keywords: private pensions, participation, self-selection, policy effects

Corresponding author:

Nadia Karamcheva

Urban Institute

2100 M Street NW

Washington, DC 20037

USA

E-mail: nkaramcheva@urban.org

\footnotetext{
* The authors would like to thank Norma Coe, Peter Gottschalk, Alicia Munnell, Austin Nichols, Shannon Seitz, and participants at the 16th annual meeting of the Society of Labor Economists, the Boston College Labor Economics Lunch Seminar, and the Urban Institute Brown Bag Seminar for valuable comments and suggestions. The opinions and conclusions are solely our own and should not be construed as representing the opinions of Analysis Group, Boston College or the Urban Institute. All mistakes are our own.
} 


\section{Background}

Over the last thirty years, defined contribution (DC) pension plans have become the norm in the private sector in the U.S, as employers have used them to replace more traditional defined benefit (DB) plans. Unlike DB plans, workers offered a DC plan are not required to participate. Because participation often requires a contribution out of one's salary and into a tax-deferred savings account, many individuals choose not to take-part in the plan, even when eligible. The decision not to participate in an available DC plan is especially common amongst low-income individuals, who are also less likely to be offered a plan in the first place. ${ }^{1}$ This "double-whammy" of high rates of voluntary non-participation and low rates of DC availability amongst low-income workers has become a serious concern of policy makers, especially as demographic shifts and impending reforms will likely result in Social Security replacing a smaller share of preretirement earnings in the future. ${ }^{2}$

While analysts debate the degree of retirement preparedness, most agree that within the bottom of the income distribution there is a significant share of individuals at risk of not being able to maintain their standard of living in retirement. ${ }^{3}$ One suggested approach for improving the retirement security of this group, which has recently gained momentum, focuses on shrinking or eliminating the gap in pension coverage and/or sponsorship between low-income workers and

\footnotetext{
${ }^{1}$ For example, see Karamcheva and Sanzenbacher (2010).

${ }^{2}$ Butrica, Smith and Iams (2012) compare sources and levels of retirement income across cohorts, while Wu et al. (2013) examine how demographic and labor force participation factors are already and will continue to affect Social Security replacement rates.

${ }^{3}$ Among the more conservative estimates are those of Munnell, Webb and Gosub-Sass (2012) who show that overall 53 percent of individuals have not saved enough. Scholz, Sedhadri and Khitatrakun (2006) are much more optimistic at only 20 percent, while Hurd and Rohwedder (2012) fall in between at 29 percent.
} 
others. Simply put, the policy would require firms that currently do not offer retirement plans to set up individual retirement accounts (IRAs) or a form of taxdeferred retirement savings vehicles for their employees. ${ }^{4}$

Yet, given the voluntary nature of participation in these tax-deferred, DCtype saving vehicles, it is unclear how effective such a policy would be, since low-income workers could always decline to participate. Advocates of the policy note that even among low-income workers, the majority of individuals offered a DC pension plan participate. Thus, it would follow that if more low-income workers had access to a plan, most would participate. Of course, care must be taken in rendering this interpretation. As is always the case when looking at a group that has self-selected into an outcome (e.g., college entry, program participation, etc.) one must be concerned that the group that has selected in, in this case workers offered a DC pension, differ in unobservable ways from those who did not. Thus, in this paper we control for selection into the pensioned job. In doing so, we seek to answer the fundamental question of interest to policy makers: how likely are workers, and in particular low-income workers, to participate in a DC pension plan that they did not have access to prior to the policy? To our knowledge, this is not a question that has been addressed in the literature to date.

DC plans have been present and gaining popularity for more than thirty years now, which in turn has stimulated a growing literature that examines the determinants of individuals’ participation and saving decisions in these plans. Studies have used varied sources of data -household survey data, administrative earnings and contribution data, employee records in specific firms, as well as

\footnotetext{
${ }^{4}$ The Automatic IRA, conceived by Mark Iwry of the Brooking Institution and David John of the Heritage Foundation in one such proposal (Iwry and John 2007). Recent proposals were introduced in the House of Representatives by Congressman Richard Neal -Automatic IRA Act of 2012 (H.R. 4049); and in the Senate by Senator Jeff Bingaman -Automatic IRA Act of 2011 (S.1557). A similar plan was included in the president's fiscal year (FY) 2013 budget.
} 
plan-level data, and have found generally similar results. Among the strongest positive determinants of participation and contribution are age, marital status, income or earnings, wealth, education, as well as the existence of an employer match and more recently, the plan having an automatic enrollment provision (Bassett, Fleming and Rodrigues 1998; Beshears et al. 2010; Dushi, Iams and Tamborini 2011; Even and Macpherson 2005; Huberman, Iyengar and Jiang 2007; Kusko, Poterba and Wilcox 1998; Munnell, Sunden and Taylor 2003). Whereas previous studies have used a variety of empirical techniques, they have all based their analysis on individuals who currently have access to a plan through their employer. However, that does not include the entire population of workers and importantly does not include workers without a plan; the group policy makers are most interested in with respect to the automatic-IRA policy. This paper addresses this deficiency by estimating a participation model that controls for selection into a plan, allowing accurate out-of-sample (i.e., to individuals without a pension) predictions on the effect of expanding pension coverage. We find that individuals currently without a DC pension are less likely than those with a pension to participate in an offered DC plan, even when controlling for observable characteristics. Thus, while the expansion of DC plans to workers not currently covered by such plans will improve pension coverage, the effect may not be as large as expected based on currently observed pension participation rates.

\section{Data and Trends in Pension Coverage and Participation}

Pension participation is the result of two events: 1) access to a retirement plan through an employer, and 2) the individual's enrollment in the plan. Using 
data from the March Supplement of the Current Population Survey (CPS), figures 1 through 3 document trends in pension access and participation, drawing comparisons among income groups. Figure 1 shows the share of individuals working for an employer that sponsors a plan over the last three decades. Plan sponsorship clearly differs by earnings group. Less than one third of individuals in the bottom third of earnings, work for an employer that sponsors a plan, compared with close to 70 percent for the highest earnings group. ${ }^{5}$ Except for the last decade and despite the shift from DB to DC plans, pension sponsorship has remained relatively stable and it has been evolving similarly for the three earnings groups.

In contrast, the participation rates for workers whose employers provide a plan have shown considerable divergence among earnings groups over time (see figure 2). While workers in the top third have had a nearly constant participation rate over the past 30 years, the rate for the middle third declined considerably from 95 to 86 percent - and for the lowest third fell sharply - from 85 to 65 percent. Although the CPS does not ask about the type of pension plan an individual has, these declines in participation have occurred as pensions have shifted from mandatory (DB) to voluntary (DC) plans.

The data on pension access (figure 1) and participation (figure 2) together determine the overall participation rate, as shown in figure 3. The biggest drops in overall participation occurred among middle and low earners, where the rate fell by 28 and 45 percent (or 20 and 17 percentage points), respectively. These declines drive policy makers' interest in expanding pension coverage. Yet, decreasing participation rates among low earners at sponsoring employers seems to be the bigger driver of the group's overall decline in participation rather than any dramatic change in its access to pensions. Still, the fact that low-income

\footnotetext{
${ }^{5}$ Earnings were defined as the reported monthly earnings on the first listed job. All charts are produced by using person-level weights.
} 
workers participate in offered plans a majority of the time leaves policy makers hopeful that an expansion of pension coverage would result in a large increase in pension participation.

However, it is unclear whether workers not currently offered pensions would participate at this high of a rate. To the extent that workers not offered plans differ from those offered plans, either observably or unobservably, the participation rate may be lower amongst workers covered by the new 401(k)-type plans. Thus, when making out-of-sample predictions, these characteristics must be controlled for. Because the CPS does not provide the necessary set of sociodemographic characteristics or pension information needed for a more rigorous analysis of the determinants of participation in 401(k) plans, we turn to the Survey of Income and Program Participation (SIPP), which is a national household survey overseen by the U.S. Census Bureau.

We use data from the 2001 panel of the SIPP, in which workers were asked a topical module entitled "Retirement Expectations and Pension Plan Coverage.” This topical module was conducted in 2004 and posed a series of questions on whether or not workers' present employer provided a pension, whether or not the individual participated in that pension, the type of pension the individual was offered, and whether the employer provides a matching contribution. ${ }^{6}$ This information, combined with the SIPP's core information on individuals' demographic characteristics and employer attributes make the SIPP a good data set for estimating the relationships we have in mind.

\footnotetext{
${ }^{6}$ We did not use the earlier 1996 panel, which also had the topical pension coverage module, because it was missing an important variable -- the "availability of employer match". In the 1996 panel, the question was not asked to non-participants in the DC plan. The later panels 2004 and 2008 were not appropriate because the data collected is from a period when the automatic enrollment feature increased in popularity and has been shown to have strong effects on participation. However, the SIPP data does not collect information on automatic enrollment and we are not able to control for its effect. The last section of the paper elaborates on this issue.
} 
The SIPP asks individuals if their employer sponsors a pension plan and if they participate in it. For workers who participated in their plan, individuals who claimed their benefit was based on earnings or years on the job are classified as having been offered a defined benefit plan, as their main plan, while workers who claimed they had an individual account plan are classified as being offered a defined contribution plan. Besides asking about their main plan, the SIPP includes an additional question about the availability and participation in a tax-deferred plan, similar to a 401(k), the answers to which we also take into account in determining the overall pension availability at the job.

Aside from pension plans, the core data of the SIPP provides information on individual and employer characteristics that are likely to be associated with pension offers and participation. This information includes an individual's age, race, education, marital status, whether he has children, tenure at the firm, and state of residence. The data also include individuals' income from work and net worth. On the employer side, the size of the worker's employer, and the industry of employment were also obtained from the SIPP. Tables 1 through 5 present descriptive statistics of the workers in our sample. These descriptive statistics suggest workers sort into pensioned jobs, in observable ways for certain and perhaps in ways that are unobservable.

Table 1 examines pension coverage by type of plan across income groups. Overall 64.1 percent of the workers in our sample work for an employer who sponsors a pension plan: 43.6 percent are at a firm that has a DC plan, and 25.5 are at a firm with a DB plan. ${ }^{7}$ Overall pension coverage increases by income terciles - 43.4 percent for the bottom income group compared with 81.4 percent for the top one. In addition, both DC and DB coverage increase with income: 28.6 percent of those in the bottom income tercile have access to a DC plan and 16.4

\footnotetext{
${ }^{7}$ These are not exclusive categories, as some employers sponsor both types of pensions.
} 
have DB coverage, compared with those at the top where 54.8 percent have DC coverage and 34.5 percent have a DB plan.

Table 2 shows differences in observable characteristics of those who are currently at firms that sponsor pensions compared to those who are not. The descriptive statistics show that workers at pensioned jobs are significantly less likely to be female, more likely to be married, are older and have longer tenure at the job. Those at pensioned jobs are also much more likely to have a college degree. These observable differences suggest workers may sort into pensioned jobs, but are also consistent with the notion that "better" jobs that hire more experienced or educated workers are also more likely to offer pensions. If these observable differences were the only source of the selection, we would expect the differences to dissipate once we control for income.

Table 3 compares the characteristics of workers at firms with DC plans and those without DC plans, while also controlling for income. We continue to observe significant differences. Even within each income tercile, workers at jobs with DC plans are more likely to be married, less likely to not have a high school degree, significantly more likely to have a college degree, and have higher median income and earnings than those without DC plans. These results suggest that pension coverage is not random in the population, and that there might be some unobservable factors in addition to observable factors that are behind the sorting mechanism of workers into firms with different pension coverage.

As mentioned earlier, pension participation is the result of pension sponsorship, eligibility and the decision to participate. Since the goal of the empirical specification in the next section is to uncover the determinants of voluntary participation, the focus is on individuals who are both in jobs with employer plans and are eligible to participate. As table 4 shows, 43.6 percent of workers in our sample are with an employer that sponsors a DC-type plan, however only 36.7 percent are eligible to participate. Both eligibility and 
voluntary participation correlate highly with income. Eligibility is particularly low among low-income workers - 18.3 percent of those in the bottom income tercile are eligible to take part in a DC plan, compared with 50.8 percent of those at the top third of the income distribution. Among workers who are eligible, 76.5 percent chose to participate - 59.2 percent for those in the lowest income tercile, compared with 84.9 percent for those in the highest.

Table 5 provides a descriptive analysis of some of the main determinants of voluntary plan participation within the sample of workers with access (those who work for an employer who sponsors a plan and are eligible to participate) and motivates the observable variables to be included in our analysis. The statistics are consistent with prior research and show that participants are more likely to be male and to be married, are older, and have been with the employer on average 4 years longer. Those who participate are also more educated and have significantly higher median income and net worth. Finally, the existence of an employer match is an important determinant of plan participation - overall participation rate is 86 percent in firms that match employees' contributions, and 71.2 in those that do not. $^{8}$

Overall, the descriptive statistics show significant differences between the socio-economic characteristics of workers currently at jobs with pension plans and those without, and further between participants and non-participants. Some are not surprising, as the standard life-cycle model would suggest some factors

\footnotetext{
${ }^{8}$ Most previous studies find that employees respond positively to the existence of an employer match. Even and MacPherson (2005) estimate that employer matches increase participation by about 30 percentage points. Munnell, Kopcke, Golub-Sass and Muldoon (2009) also find a significant positive effect of the employer match on contribution rates, although the relationship is concave with respect to the size of the match. Similarly, Bassett, Fleming and Rodrigues (1998) find that workers with employer matches are more likely to participate in 401(k) plans than workers without such matches. Engelhardt and Kumar (2007) estimate that the elasticity of participation with respect to matching ranges from 0.02-0.07. There is less conclusive evidence that the level of the match matters, however. Recently Dworak-Fisher (2011) found a significant positive effect of the employer match rate, while controlling for the endogeneity of employer matching.
} 
such as age, education, marital status, current versus permanent income to be important determinants of current savings rate, and thus plan participation.

However, the differences remain wide even within income groups and suggest that there might be other, potentially unobservable factors at play, which affect both selection into a pension-type job and voluntary participation.

Put differently, workers who are currently at DC sponsoring jobs may be potentially different from those who are not, due to unobservable differences in tastes or constraints, which make them more or less likely to participate in an offered DC plan. If this is the case, estimating the effects of potential participation determinants only on the selected sample would give biased and inconsistent results for the population coefficients. Moreover, if the self-selection and the decision to participate are positively correlated, policies aimed at providing voluntary savings plans to non-pensioned individuals would likely have lower participation rates than are seen in the pensioned population. Employers offering either an "Auto-IRA” or a DC-type plan should expect lower participation than might be indicated when examining the current covered population. ${ }^{9}$ The next two sections describe our empirical strategy and results of estimating the determinants of pension plan coverage and voluntary participation.

\section{Empirical Strategy}

\footnotetext{
${ }^{9}$ While the automatic IRA proposals suggest enrolling workers by default, it is reasonable to expect that workers who do not participate in DC-type plans due to their low income would opt out of the plan, while it seems possible that workers declining participation for other reasons to might stay in the plan due to inertia. Our empirical work implicitly assumes that the decision to decline participation in an offered DC-type plan would be similar to the decision to opt out of an "Auto-IRA" type plan.
} 
In our empirical approach, we start with a standard probit specification to model the decision to participate in an offered 401(k) plan, estimated on the sample of individuals who are working for an employer sponsoring a 401(k) plan and are eligible to participate (see equation 1 ). This provides us with results easily comparable to those in previous literature.

\section{A. Probit:}

$$
\begin{aligned}
& y^{*}=x^{\prime} \beta+\varepsilon \quad \text { where } \varepsilon \sim \mathcal{N}\left(0, \sigma^{2}\right) \\
& y=\left\{\begin{array}{l}
1 \text { if } y^{*}>0 \\
0 \text { if } y^{*} \leq 0
\end{array}\right. \\
& \text { or }
\end{aligned}
$$

$$
\mathrm{p}=\operatorname{Pr}[\text { Participate }=1 \mid \mathrm{x}, \text { Offered } \mathrm{DC}=1]=\Phi\left(\mathrm{x}^{\prime} \beta\right)
$$

where $y^{*}$ is latent propensity to participate and $\mathrm{x}=\{$ demographics, tenure at current job, annual income, wealth, etc.\}

In the specifications that follow we allow the unobservable that affects the probability of being offered a 401(k) plan to be correlated with the unobservable that affects the worker's decision to choose participation. The empirical setup that achieves this in the probit specification is a bivariate probit model with sample selection as described in Green (2008). This formulation was first presented by Van de Ven and Van Pragg (1981) and applied to our question of interest has the following basic set up, which builds on equation (1).

\section{B. Bivariate Probit with Sample Selection:}

$$
y_{1}^{*}=\mathrm{x}_{1}{ }^{\prime} \beta_{1}+\varepsilon_{1} \quad \text { where } \varepsilon_{1} \sim \mathcal{N}\left(0, \sigma^{2}{ }_{1}\right)
$$




$$
y_{2}^{*}=\mathrm{x}_{2}{ }^{\prime} \beta_{2}+\varepsilon_{2} \quad \text { where } \varepsilon_{2} \sim \mathcal{N}\left(0, \sigma_{2}^{2}\right)
$$

where $y_{1}^{*}$ and $y_{2}^{*}$ are two latent variables observed according to the following rule:

$$
\begin{aligned}
& y_{1}^{*}= \begin{cases}1 \text { if } & y_{1}^{*}>0 \\
0 \text { if } & y_{1}^{*} \leq 0\end{cases} \\
& y_{2}^{*}= \begin{cases}1 \text { if } & y_{2}^{*}>0 \text { and } y_{1}^{*}>0 \\
0 \text { if } & y_{2}^{*} \leq 0 \text { and } y_{1}^{*}>0 \\
- & \text { if } y_{1}^{*} \leq 0\end{cases}
\end{aligned}
$$

$\mathrm{x}_{1}$ and $\mathrm{x}_{2}$ are vectors of exogenous variables, the error terms are assumed to be independently and identically distributed as bivariate normal, and $\rho$ is the correlation parameter.

$$
\left[\begin{array}{l}
\varepsilon_{1} \\
\varepsilon_{2}
\end{array}\right] \sim \mathcal{N}\left[\left[\begin{array}{l}
0 \\
0
\end{array}\right],\left[\begin{array}{cc}
1 & \sigma_{12} \\
\sigma_{12} & \sigma_{2}^{2}
\end{array}\right]\right] \quad \text { or } \quad\left[\begin{array}{l}
\varepsilon_{1} \\
\varepsilon_{2}
\end{array}\right] \sim \mathcal{N}\left[\left[\begin{array}{l}
0 \\
0
\end{array}\right],\left[\begin{array}{ll}
1 & \rho \\
\rho & 1
\end{array}\right]\right]
$$

Alternatively we can write the model in the following way where equation (5) models the probability of being offered a DC plan, and equation (6) models the likelihood of participating if offered. Since the correlation coefficient $\rho$ denotes the extent to which the two errors covary, when $\rho \neq 0$, standard probit techniques applied to equation (6) yield biased results. To achieve a consistent and asymptotically efficient estimate of $\beta_{2}$ we need to account for the sample selection and estimate the two equations jointly. The parameter vector $\beta=$ $\left(\beta_{1}, \beta_{2}, \rho\right)$ can be recovered via by maximum likelihood.

$$
\begin{aligned}
& \mathrm{p}_{1}=\operatorname{Pr}[\text { Offered DC }=1]=\Phi\left(\mathrm{x}_{1}{ }^{\prime} \beta_{1}\right) \\
& \mathrm{p}_{2}=\operatorname{Pr}[\text { Participate }=1 \mid \text { Offered DC }=1]=\Phi\left(\mathrm{x}_{2}^{\prime} \beta_{2}\right)
\end{aligned}
$$




\section{Identification}

Although most selection type models are technically identified simply through functional form, it has become an established practice in the literature to include at least one exclusion regressor in the selection equation as a way to improve identification and lead to more stable and reliable estimates. This exclusionary regressor should affect the probability an individual is offered a DC pension (selected) without influencing pension participation (the outcome). ${ }^{10}$ For this purpose, we have chosen several variables that vary by state of residence and reflect the availability of DC plans. These variables are the ratio of defined contribution plans to all pension plans, the proportion of firms with more than 100 workers, and the proportion of firms with 25 to 99 workers in a worker's state of residence. Our assumption is that these variables capture variation in the availability of 401(k) plans coming from the employer side and are exogenous factors in the workers' saving decisions.

Although it is impossible to test the validity of the exclusion restrictions, simple OLS regressions results suggest that these variables are strongly correlated with the probability a person is offered a defined contribution plan and are not significant determinants of the decision to participate. For these to be valid exclusion restrictions, the underlying assumption is that people do not move to a state because they are more likely to participate in a defined contribution plan once offered. This would be the case if, for example, individuals moved to a state because the culture was one of thrift and they identified with that culture, or if state-wide preferences towards savings and tax-deferred forms of compensation are simultaneously leading to more firms offering plans and more workers choosing to participate. This is indeed a possibility, which would severely

\footnotetext{
${ }^{10}$ For a discussion of this point, see Cameron and Trivedi (2006) at p. 551.
} 
jeopardize the validity of our instruments, and which unfortunately we are not able to fully control for without having information on individuals' preferences for saving. Instead, to mitigate the confounding effects of such unobservable factors, we include controls for political attitudes and net migration flows by state. Specifically, we include year 2004 state-wide political attitudes in the form of percent leaning democrat, and the democrat-republican percentage gap, as well as a variable that captures net state migration between 2004 and 2005. ${ }^{11}$

\section{Results}

\section{A. Determinants of Participation}

Table 6a compares estimates from a standard probit model with one which in addition controls for selection. Specifications 2) through 5) differ based on the availability of additional controls and exclusion restrictions. Table $6 \mathrm{~b}$ presents the estimated marginal effects of the same specifications.

The results of the probit and the probit with selection are largely consistent with the literature with respect to sign and significance. Similarly to previous studies, ${ }^{12}$ we find that individuals who are married, well educated, have high tenure at their firm, and work at firms with an employer match are all more likely to participate than others. Blacks and younger individuals are less likely to participate, and so are women as compared with men. Also consistent with expectations, individuals with high wealth and high income are more likely to participate in an offered defined contribution plan than other individuals.

\footnotetext{
${ }^{11}$ We use by state net migration rate between 2004 and 2005 provided by the U.S. Census Bureau, using 2005 ACS. For political attitudes we use data from a 2004 Gallup poll identifying by state percent leaning democrat and the republican-democrat gap. Data can be found here: http://www.gallup.com/poll/14746/gallup-review-party-support-2004.aspx.

${ }^{12}$ See for example Bassett, Fleming and Rodrigues (1998) and Munnell, Kopcke, Golub-Sass and Muldoon (2009).
} 
Interestingly, having a DB plan is positively correlated with participation in a DC plan in the probit specification, but its coefficient turns negative and its significance disappears in the specifications with selection. Having a DB plan, however is strongly negatively associated with being offered a DC plan in the first place, likely driven by the fact that employers who already sponsor a DB plan are less likely also sponsor a DC plan. The positive coefficient of having a DB plan in the probit specification could be the result of self-selection of more saving-prone individuals into jobs with pension plans.

The estimated correlation coefficient is positive and strongly significant in specifications 2) through 5) and so are the coefficients on the exclusion restrictions. These results support the hypothesis of a possible self-selection effect and suggest that indeed individuals in defined contribution jobs are more likely to participate than similar individuals in jobs not offering these pension plans, based on factors unobservable to the estimation. Table 6a also shows the importance of the instruments for improving identification. Not using any additional factors to identify the selection separately from the main equation, results in an overestimated correlation coefficient (see model 2) and somewhat overestimated marginal effects for most variables (table 6b, model 2).

Our preferred specification is model 4) as it results in the most conservative estimate of correlation between the two equations, yet the estimated coefficients on the main variables of interest have high significance and intuitive direction. The estimated marginal effects in table $6 \mathrm{~b}$ show that women have 0.071 lower probability of participation in an offered 401(k) plan, while being married raises the probability by 0.10 . Having a college degree is associated with a 0.113 higher likelihood of participation, having children however decreases it by 0.03 . The existence of an employer match is also an important determinant raising the probability of participation by 0.21 . Both income and wealth are also significant determinants with marginal effect of $\log$ (income) and $\log$ (wealth) of 0.044 and 
0.035 respectively. Overall the results of models 3) through 5) are not surprising previous literature has already documented similar (in terms of direction and significance) relationships between the independent variables and 401(k) plan participation. What is interesting is the change in the magnitudes of the effects comparing this specification with a more standard probit on the selected sample specification (model 1). Not allowing for the correlation between the errors terms in the DC offer and participation equations results in underestimation of the population effects of many of the important participation determinants. From a policy point a view if the goal is to predict the effect of policies targeted at the whole population, using estimates based on specifications 3) through 5) might result in better population predictions.

\section{B. Pension Participation Gap with Universal Coverage}

Tables 7a and 7b illustrate this point by comparing predicted participation rates by income groups using the results from tables 6 a. Given the dichotomy of the employer match provision, instead of assuming a match structure that will be available to currently uncovered individuals, we present two scenarios. Table $7 \mathrm{a}$ assumes that all defined contribution plans offer a match at the same rate as the average firm in our sample, while table $7 \mathrm{~b}$ assumes that none of the existing or future defined contribution plans provide a match. Both tables show a considerable participation gap that remains between low and high income individuals. To the extent that universal coverage is achieved through the expansion of similarly in nature to the existing tax-deferred voluntary participation plans, policy makers should expect a remaining participation gap between low and high earners ranging between 24 and 35 percent, and a lower on average coverage rate than the one observed in current pension-sponsoring jobs. 
The benefit of controlling for the unobserved characteristics of individuals that select into pensioned jobs can be seen by examining Table 7a. A simple probit, which exploits only observable features of the data, would predict a participation rate of 65 percent in the lowest income tercile if all individuals were offered a defined contribution pension plan. Once unobservable characteristics are taken into account the predicted participation rate drops to 46 percent. This analysis illustrates that policy makers should be wary of basing predictions regarding the success of expanding pension coverage on those currently covered.

Missing from our analysis is the effect of automatic enrollment - an increasing in popularity feature of DC plans. In contrast to the standard opt-out regime, under which individuals have to take active steps to participate in the plan, under automatic enrollment eligible workers are enrolled by default unless they actively opt-out of the plan. The Pension Protection Act of 2006 included a number of provisions that encouraged the adoption of automatic enrollment and it has been increasing in popularity ever since (PSCA 2012; Purcell 2007 ). Previous literature has documented that firms that switched from opt-in to opt-out regimes experienced significant increase in their employees' participation rates, sometimes even in the absence of an employer match (Beshears et al. 2010; Choi et al. 2004; Madrian and Shea 2001).

Unfortunately data limitations do not allow us to control for the effect of this provision. To the extent that the effect of automatic enrollment on participation might differ based on workers’ observed and unobserved characteristics, the results presented above should be interpreted with caution. On the other hand, the current estimates of the effect of the automatic enrollment provision are all based on firm-level studies that follow workers' actions for a relatively short period of time and are not yet able to capture the long-term population-wide effects on participation. To the extent that low-income workers are more likely to opt-out (e.g. due to liquidity constraints), and as a result are less 
influenced by these provisions, the estimates of the remaining participation gap (tables $7 \mathrm{a}$ and $7 \mathrm{~b}$ ) will likely not be too far off from the true population effects event if automatic enrollment becomes the norm in the future. Moreover, recent papers point to the possibility of employers responding to the increased costs of automatic enrollment by setting relatively low default contribution rates or lowering the employer match or employer contribution rates in their plans, which in turn might decrease workers' benefit of participating (Butrica and Karamcheva 2012; Soto and Butrica 2009). The extent to which the effects of instituting automatic enrollment on one hand, and employers' cost-reducing actions on the other hand, might have offsetting effects on participation, is an interesting avenue for future research.

\section{Conclusion}

Over the last three decades, pension participation in the U.S. amongst lowincome individuals has dropped in half to just above 20 percent. Policy makers and researchers have sought to remedy this decline, and given that private pension plans currently cover only half of the workforce, some of the suggested proposals have called for extending the availability of tax-deferred private saving vehicles, similar to 401(k)s or IRAs to all workers, thus achieving almost universal coverage. Given the voluntary nature of participation in these plans, however, having access to a plan, often does not translate into actually participating and contributing to the plan. Understanding what determines participation is vital in assessing the potential effects of policy proposals.

Using data on workers currently at employers who sponsor plans, previous literature has consistently identified certain factors such as age, education, marital status, tenure, income, wealth, and the availability of an employer match, as 
important determinants of participation. Using data from the 2001 panel of the SIPP, this paper confirms those findings, but also builds on previous results by controlling for an important but often omitted factor that affects individuals' choice of participation. Observations of significant differences in characteristics between workers at pension jobs and those without, as well as between participants and non-participants hint at potential unobservable factors that might be behind the self-selection of workers with higher propensity to save into jobs that offer tax-deferred savings plans. The implication of this selection is that individuals who are currently at jobs with no pension plans may be especially unlikely to contribute, when given the option. Our estimates suggest that this selection effect is non-trivial. Whereas, extending tax deferred plan coverage will likely lead to increased participation on average, our findings point to a remaining participation gap between low- and high-income workers between 24 and 35 percentage points, which might be higher than what policy makers hope for and expect based on the participation patterns of workers currently offered these kinds of pensions. 


\section{REFERENCES}

Bassett, William. F., Michael J. Fleming, M. J., and Anthony. P.Rodrigues. 1998.” How Workers Use 401(k) Plans: The Participation, Contribution, and Withdrawal Decisions.” National Tax Journal, 51: 263-89.

Beshears, John, James J. Choi, David Laibson, and Brigitted C. Madrian. 2010. "The Impact of Employer Matching on Savings Plan Participation under Automatic Enrollment.” In Research Findings in the Economics of Aging, edited by David A. Wise. Chicago, IL: University of Chicago Press.

Butrica, Barbara A., Nadia S. Karamcheva. 2012. "Automatic Enrollment, Employee Compensation, and Retirement Security.” Urban Institute Program on Retirement Security Discussion Paper 12-02

Butrica, Barbara A., Karen E. Smith, and Howard M. Iams. 2012. "This is Not Your Parents’ Retirement: Comparing Retirement Income Across Generations.” Social Security Bulletin, 72: 37-58.

Cameron, A. Colin, and Pravin K. Trivedi. 2006. Microeconometrics: Methods and Applications. New York, NY: Cambridge University Press.

Choi, James J., David Laibson, Brigitte C. Madrian, and Andrew Metrick. 2004. "For better or for worse: Default Effects and 401(k) Savings Behavior." In Perspectives in the Economics of Aging, edited by David A. Wise, 81-121. Chicago, IL: University of Chicago Press.

Dushi, Irena, Howard Iams, and Christopher R. Tamborini. 2011. "Defined Contribution Pension Participation and Contributions by Earnings Levels Using Administrative Data.” Social Security Bulletin, 71: 67-76.

Dworak-Fisher, Keenan. 2011. "Matching Matters in 401(k) Plan Participation.” Industrial Relations, 50: 713-737.

Engelhardt, Gary V., and Anil Kumar. 2007. "Employer Matching and 401(k) Saving: Evidence from the Health and Retirement Study." Journal of Public Economics, 91.

Even, William. E., David A. MacPherson. 2005. “The Effects of Employer Matching in 401(k) Plans.” Industrial Relations, 44: 525-49. 
Green, William. H. 2008. “Discrete Choice Modeling.” In Palgrave Handbook of Econometrics, edited by Terence C. Milles and Karry Patterson, 473-556. London: Palgrave.

Huberman, Gur, Shena S. Iyengar, and Wei Jiang. 2007. “Defined Contribution Pension Plans: Determinants of Participation and Contribution Rates.” Journal of Financial Services Research, 31:1-32.

Hurd, Michael D., and Susann Rohwedder. 2012. "Economic Preparation for Retirement.” In Investigations of the Economics of Aging, edited by David A. Wise, 77-118. Chicago:University of Chicago Press.

Iwry, J. Mark, and David C. John. 2007. "Pursuing Universal Retirement Security Through Automatic IRAs.” Retirement Security Project Paper 20072

Karamcheva, Nadia S. and Geoffrey Sanzenbacher, 2010. "Is Pension Inequality Growing? ” Center for Retirement Research at Boston College Issues in Brief, 10-1.

Kusko, Andrea L., James M. Poterba, and David W. Wilcox. 1998. “Employee Decisions With Respect to 401(k) Plans.” In Living with Defined Contribution Pensions, edited by Olivia S. Mitchell and Sylvester J. Schieber, pp. 98-112. Philadelphia, PA: Pension Research Council and the University ofPennsylvania Press.

Madrian, Brigitte C., and Dennis F. Shea. 2001. "The Power of Suggestion: Inertia in 401(K) Participation and Savings Behavior.” The Quarterly Journal of Economics, 116: 1149-1187.

Munnell, Alicia. H., Annika Sunden, and Catherine Taylor. 2003. "What Determines 401(k) Participation and Contributions?” Social Security Bulletin, 64.

Munnell, Alicia. H., Richard Kopcke, Francesca N. Golub-Sass and Dan Muldoon. 2009. "An update on 401(k) plans: Insights from the 2007 Survey of Consumer Finance.” Center for Retirement Research at Boston College Working Paper 2009-26. 
Munnell, Alicia H., Anthnony Webb, Francesca N. Golub-Sass. 2012. "The National Retirement Index: An Update.” Center for Retirement Research at Boston College Issue in Brief 12-20.

Plan Sponsor Council of America (PSCA). 2012. “55th Annual Survey.” PSCA's Annual Survey of Profit Sharing and 401(k) Plans. http://www.psca.org/55th_survey

Purcell, Patrick. 2007. “Automatic Enrollment in 401(k) Plans.” Congressional Research Service Report for Congress. http://www.aging.senate.gov/crs/pension18.pdf

Soto, Maurico, and Barbara A. Butrica. 2009. "Will Automatic Enrollment Reduce Employer Contributions to 401(k) Plans?” Urban Institute Program on Retirement Policy Discussion Paper 09-04.

Scholz, John K., Ananth Sedhadri, and Surachai A. Khitatrakun. 2006. “Are Americans Saving 'Optimally’ for Retirement?” Journal of Political Economy, 114: 607-643

Van de Ven, Wynand. P. M. M., and Bernand M. S.Van Pragg. 1981. "The Demand for Deductibles in Private Health Insurance: A Probit Model With Sample Selection.” Journal of Econometrics, 17:229-252.

Wu, April Yanyuan, Nadia S. Karamcheva, Alicia H. Munnell and Patrick Purcell. 2013. "How Does the Changing Labor Supply Behavior and Marriage Patterns of Women Affect Social Security Replacement Rates?” Social Security Bulletin, 73. 
Figure 1: Pension Sponsorship, all Private Sector Male Workers Age 25-64, by Earnings Tercile, 1979-2011

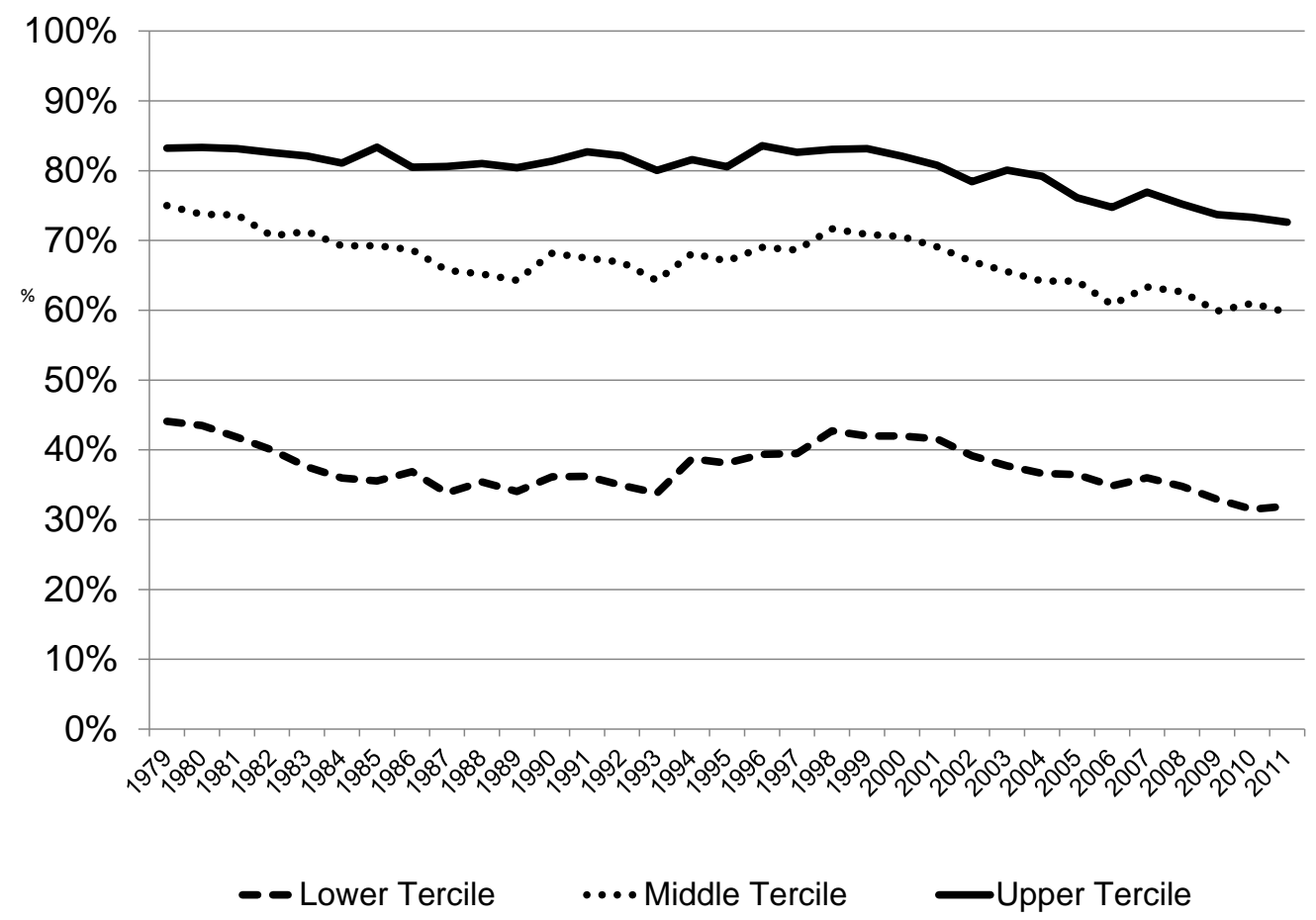

Source: Authors' calculations from U.S. Bureau of Labor Statistics, Current Population Survey (CPS) March Supplement, 1980-2012. 
Figure 2: Pension Participation Rate for Private Sector Male Workers Age 25-64 at Employers with Pensions, by Earnings Tercile, 1979-2011.

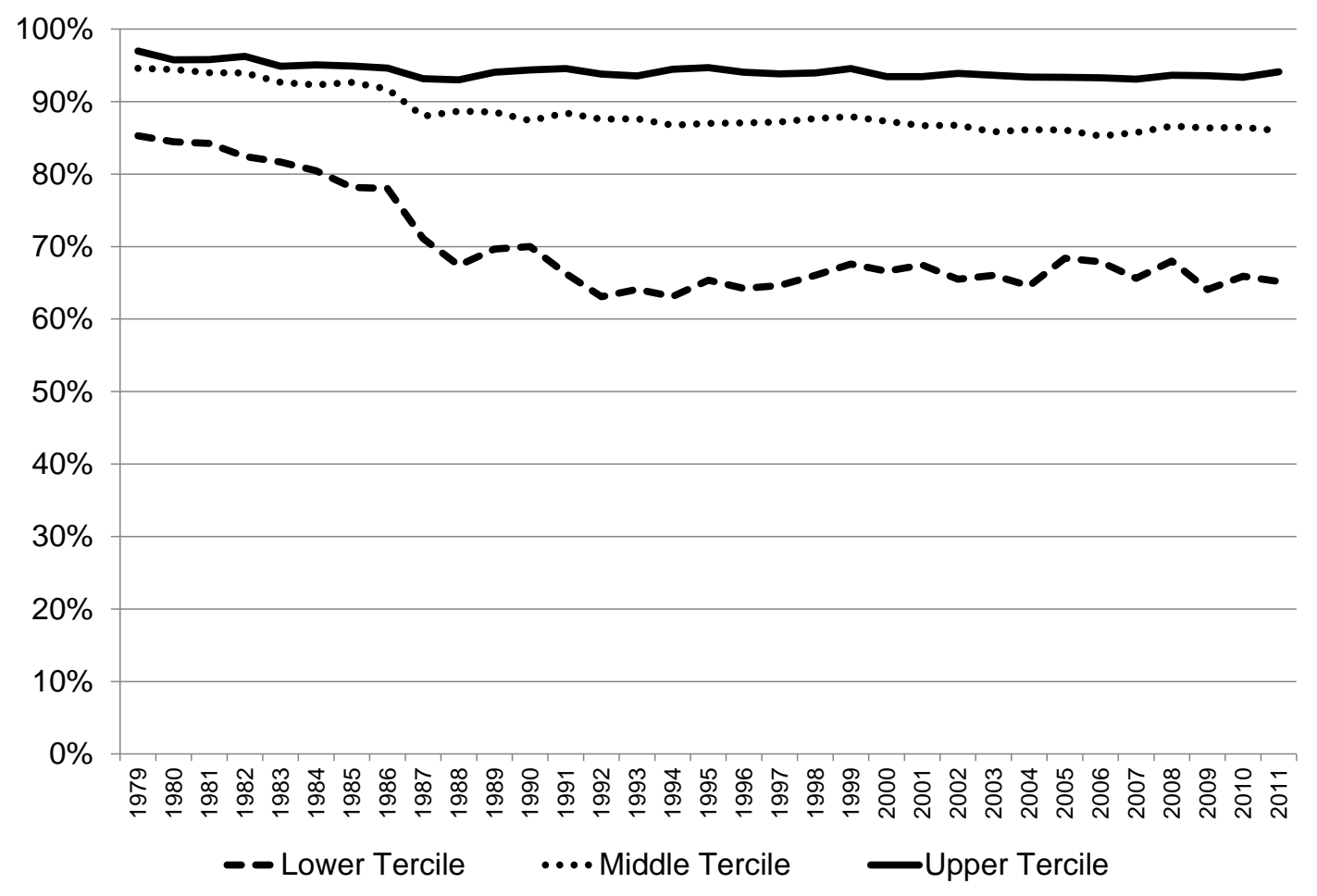

Source: Authors' calculations from U.S. Bureau of Labor Statistics, Current Population Survey (CPS) March Supplement, 1980-2012. 
Figure 3: Pension Participation Rate for Private Sector Male Workers Age 25-64, by Earnings Tercile, 1979-2011.

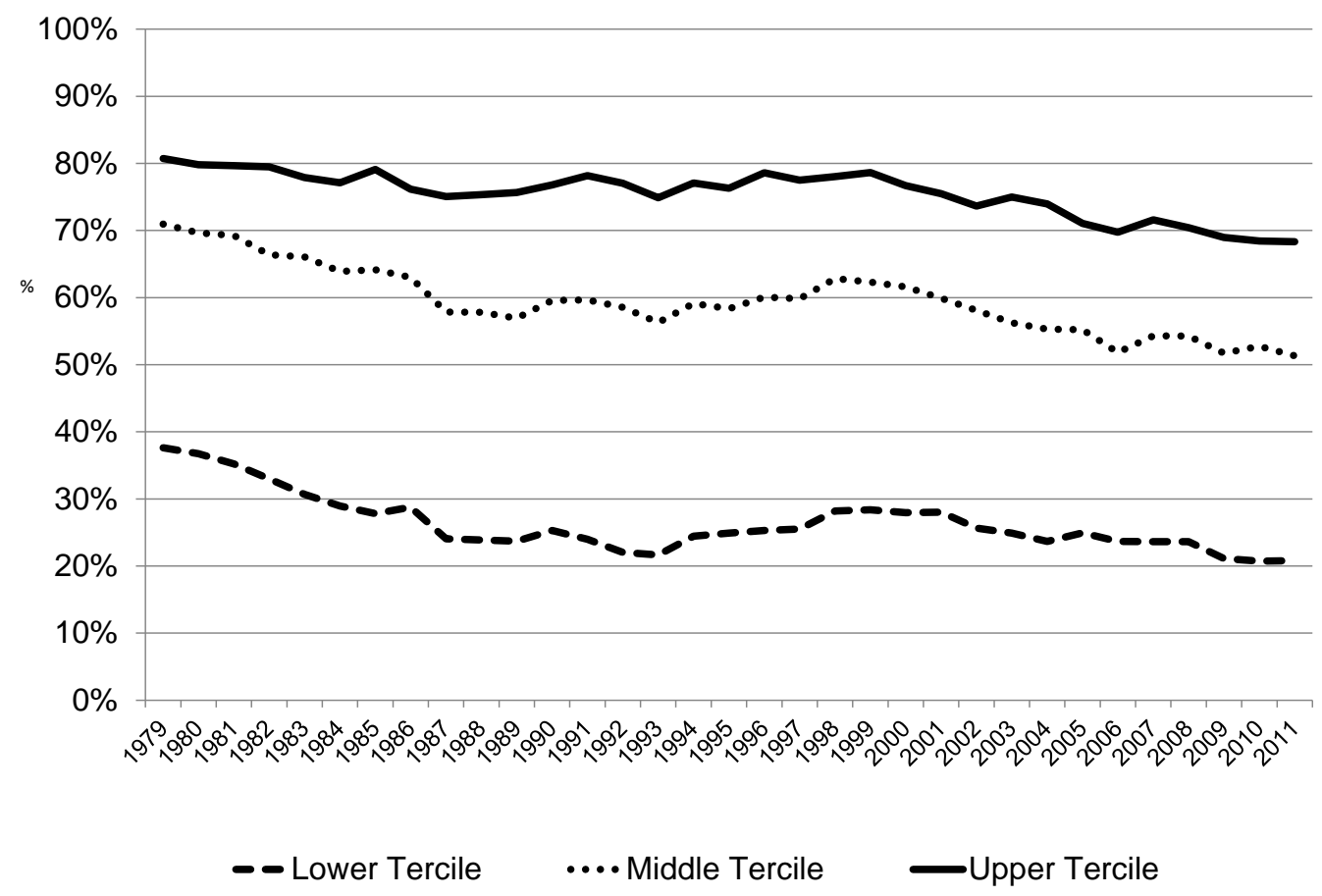

Source: Authors' calculations from U.S. Bureau of Labor Statistics, Current Population Survey (CPS) March Supplement, 1980-2012. 
Table 1: Percent of Workers with Pension Coverage by Type of Plan and by Income ${ }^{1}$

\begin{tabular}{lccc} 
& $\begin{array}{c}\text { Employer Sponsors } \\
\text { a Plan }\end{array}$ & DC plan & DB plan \\
\hline All & $64.1 \%$ & $43.6 \%$ & $25.5 \%$ \\
Lower Income Tercile & $43.4 \%$ & $28.6 \%$ & $16.4 \%$ \\
Middle Income Tercile & $65.2 \%$ & $45.6 \%$ & $24.4 \%$ \\
Upper Income Tercile & $81.4 \%$ & $54.8 \%$ & $34.5 \%$ \\
\hline
\end{tabular}

1 - Some employers sponsor both DB and DC plans

Source: Authors' calculations, based on data from the 2001 panel of the SIPP 
Table 2: Characteristics of Workers by Pension Plan Sponsorship

\begin{tabular}{lrrrrr}
\hline & $\begin{array}{r}\text { No } \\
\text { Pension } \\
\text { Plan }\end{array}$ & $\begin{array}{r}\text { Main } \\
\text { Plan is }\end{array}$ & $\begin{array}{r}\text { Main } \\
\text { Plan is }\end{array}$ & \\
& & & & & \\
\hline Female & $47.1 \%$ & $46.5 \%$ & $*$ & $45.6 \%$ & $* *$ \\
\% Married & $47.6 \%$ & $58.2 \%$ & $* * *$ & $61.0 \%$ & $* * *$ \\
\% with Children & $44.0 \%$ & $41.9 \%$ & $* * *$ & $43.0 \%$ & \\
\% White & $83.0 \%$ & $85.5 \%$ & $* * *$ & $82.3 \%$ & \\
\% Black & $11.8 \%$ & $9.5 \%$ & $* * *$ & $12.6 \%$ & $*$ \\
Average Age & 35.74 & 38.92 & $* * *$ & 41.07 & $* * *$ \\
\% with less than HS degree & $22.2 \%$ & $7.8 \%$ & $* * *$ & $8.8 \%$ & $* * *$ \\
\% HS graduates & $52.9 \%$ & $48.6 \%$ & $* * *$ & $49.4 \%$ & $* * *$ \\
\% College graduates & $24.9 \%$ & $43.5 \%$ & $* * *$ & $41.9 \%$ & $* * *$ \\
Average Tenure & 4.48 & 6.59 & $* * *$ & 9.12 & $* * *$ \\
Median income & $\$ 18,000$ & $\$ 30,000$ & $* * *$ & $\$ 33,480$ & $* * *$ \\
Median Networth & $\$ 21,100$ & $\$ 38,104$ & $* * *$ & $\$ 46,796$ & $* * *$ \\
\hline
\end{tabular}

Source: Authors' calculations, based on data from the 2001 panel of the SIPP.

Notes: Significance levels refer to conducted tests for difference in means or medians between the "no pension plan" category and the DC and DB categories respectively.

*** Significant at the 1 percent level.

** Significant at the 5 percent level.

* Significant at the 10 percent level. 
Table 3: Characteristics of Workers by DC Plan Sponsorship and by Income

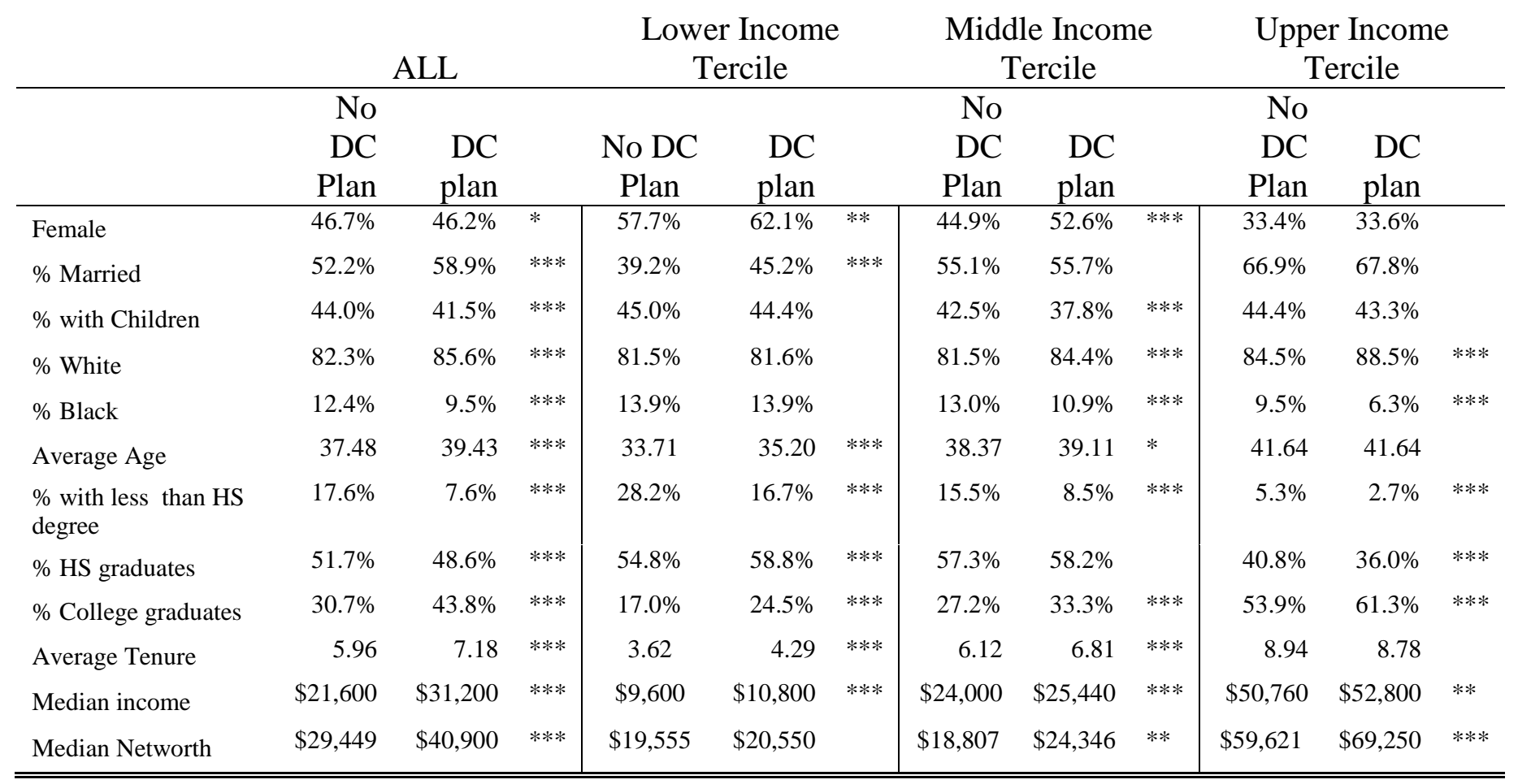

Source: Authors' calculations, based on data from the 2001 panel of the SIPP.

Notes: Significance levels refer to conducted tests for difference in means or medians between each two categories.

*** Significant at the 1 percent level.

** Significant at the 5 percent level.

* Significant at the 10 percent level. 
Table 4: 401(k) Sponsorship, Participation and Contribution Rates by Income

$\begin{array}{ccc}\begin{array}{c}\text { \% in Jobs } \\ \text { with DC }\end{array} & \text { DC J \& Eligible } & \text { \% Participating } \\ \text { if Eligible }\end{array}$

\begin{tabular}{llll} 
All & $43.6 \%$ & $36.7 \%$ & $76.5 \%$ \\
Lower Income Tercile & $28.6 \%$ & $18.3 \%$ & $59.2 \%$ \\
Middle Income Tercile & $45.6 \%$ & $38.9 \%$ & $72.6 \%$ \\
Upper Income Tercile & $54.8 \%$ & $50.8 \%$ & $84.9 \%$ \\
\hline
\end{tabular}

Source: Authors' calculations, based on data from the 2001 panel of the SIPP. 
Table 5: Characteristics of Workers by DC Plan Participation ${ }^{1}$ and by Income

\begin{tabular}{lrrr} 
& Non-Participant & \multicolumn{1}{c}{ Participant } & \\
\hline Female & $52.3 \%$ & $42.2 \%$ & $* * *$ \\
\% Married & $49.1 \%$ & $66.1 \%$ & $* * *$ \\
\% with Children & $40.0 \%$ & $41.7 \%$ & \\
\% White & $82.3 \%$ & $87.2 \%$ & $* * *$ \\
\% Black & $12.6 \%$ & $8.0 \%$ & $* * *$ \\
Average Age & 37.59 & 41.57 & $* * *$ \\
\% with less than HS degree & $8.3 \%$ & $5.9 \%$ & $* * *$ \\
\% HS graduates & $56.6 \%$ & $45.2 \%$ & $* * *$ \\
\% College graduates & $35.1 \%$ & $48.8 \%$ & $* * *$ \\
Average Tenure & 5.58 & 8.75 & $* * *$ \\
Median income & $\$ 25,380$ & $\$ 36,480$ & $* * *$ \\
Median Networth & $\$ 18,028$ & $\$ 53,302$ & $* * *$ \\
Employer Provides a Match & $71.2 \%$ & $86.0 \%$ & $* * *$ \\
\hline $1-$ Amm
\end{tabular}

1 - Among individuals in jobs with DC plan sponsorship, who are eligible. Source: Authors' calculations, based on data from the 2001 panel of the SIPP.

Notes: Significance levels refer to conducted tests for difference in means or medians between the two categories.

*** Significant at the 1 percent level.

** Significant at the 5 percent level.

* Significant at the 10 percent level. 
Table 6a: 401(k) Participation Models:

\begin{tabular}{|c|c|c|c|c|c|c|c|c|c|}
\hline & \multirow{2}{*}{$\begin{array}{c}\text { (1) } \\
\text { Probit } \\
\mathrm{Y}=\text { participate }\end{array}$} & \multicolumn{2}{|c|}{$\begin{array}{c}\text { (2) } \\
\text { Bivariate Probit with } \\
\text { Sample Selection }\end{array}$} & \multicolumn{2}{|c|}{$\begin{array}{c}\text { (3) } \\
\text { Bivariate Probit with } \\
\text { Sample Selection }\end{array}$} & \multicolumn{2}{|c|}{$\begin{array}{c}(4) \\
\text { Bivariate Probit with } \\
\text { Sample Selection } \\
\end{array}$} & \multicolumn{2}{|c|}{$\begin{array}{c}(5) \\
\text { Bivariate Probit with Sample } \\
\text { Selection }\end{array}$} \\
\hline & & $\mathrm{Y}=$ participate & $\begin{array}{c}\mathrm{Y}=\text { eligible for } \\
\text { DC }\end{array}$ & $\begin{array}{c}\mathrm{Y}= \\
\text { participate }\end{array}$ & $\begin{array}{c}\mathrm{Y}=\text { eligible } \\
\text { for DC }\end{array}$ & $\mathrm{Y}=$ participate & $\begin{array}{c}\mathrm{Y}=\text { eligible for } \\
\text { DC }\end{array}$ & $\mathrm{Y}=$ participate & $\begin{array}{c}\mathrm{Y}=\text { eligible for } \\
\text { DC }\end{array}$ \\
\hline Female & $\begin{array}{c}-0.179^{* * *} \\
(0.041)\end{array}$ & $\begin{array}{c}-0.182^{* * *} \\
(0.036)\end{array}$ & $\begin{array}{c}-0.069^{* * *} \\
(0.022)\end{array}$ & $\begin{array}{c}-0.188^{* * *} \\
(0.039)\end{array}$ & $\begin{array}{c}-0.073^{* * *} \\
(0.022)\end{array}$ & $\begin{array}{c}-0.187^{* * *} \\
(0.039)\end{array}$ & $\begin{array}{c}-0.074^{* * *} \\
(0.022)\end{array}$ & $\begin{array}{c}-0.146^{* * *} \\
(0.041)\end{array}$ & $\begin{array}{l}-0.041^{*} \\
(0.024)\end{array}$ \\
\hline Age & $\begin{array}{l}0.104^{* * *} \\
(0.013)\end{array}$ & $\begin{array}{l}0.132^{* * * *} \\
(0.012)\end{array}$ & $\begin{array}{l}0.097^{* * *} \\
(0.006)\end{array}$ & $\begin{array}{l}0.126^{* * *} \\
(0.013)\end{array}$ & $\begin{array}{l}0.100^{* * *} \\
(0.006)\end{array}$ & $\begin{array}{l}0.127^{* * *} \\
(0.013)\end{array}$ & $\begin{array}{l}0.100^{* * *} \\
(0.006)\end{array}$ & $\begin{array}{l}0.126^{* * *} \\
(0.013)\end{array}$ & $\begin{array}{l}0.096^{* * *} \\
(0.006)\end{array}$ \\
\hline$A g e^{\wedge 2}$ & $\begin{array}{c}-0.001^{* * *} \\
(0.000)\end{array}$ & $\begin{array}{c}-0.001^{* * *} \\
(0.000)\end{array}$ & $\begin{array}{c}-0.001^{* * *} \\
(0.000)\end{array}$ & $\begin{array}{c}-0.001^{* * *} \\
(0.000)\end{array}$ & $\begin{array}{c}-0.001^{* * *} \\
(0.000)\end{array}$ & $\begin{array}{c}-0.001^{* * *} \\
(0.000)\end{array}$ & $\begin{array}{c}-0.001^{* * * *} \\
(0.000)\end{array}$ & $\begin{array}{c}-0.001^{* * *} \\
(0.000)\end{array}$ & $\begin{array}{c}-0.001^{* * * *} \\
(0.000)\end{array}$ \\
\hline White & $\begin{array}{l}0.152^{*} \\
(0.089)\end{array}$ & $\begin{array}{l}0.175^{* *} \\
(0.080)\end{array}$ & $\begin{array}{l}0.107^{* * *} \\
(0.047)\end{array}$ & $\begin{array}{l}0.171^{* *} \\
(0.085)\end{array}$ & $\begin{array}{c}0.056 \\
(0.048)\end{array}$ & $\begin{array}{l}0.183^{* * *} \\
(0.087)\end{array}$ & $\begin{array}{c}0.068 \\
(0.048)\end{array}$ & $\begin{array}{l}0.183^{* *} \\
(0.086)\end{array}$ & $\begin{array}{c}0.073 \\
(0.049)\end{array}$ \\
\hline Black & $\begin{array}{c}0.100 \\
(0.108)\end{array}$ & $\begin{array}{c}0.101 \\
(0.097)\end{array}$ & $\begin{array}{c}0.040 \\
(0.058)\end{array}$ & $\begin{array}{c}0.101 \\
(0.104)\end{array}$ & $\begin{array}{c}0.004 \\
(0.059)\end{array}$ & $\begin{array}{c}0.114 \\
(0.106)\end{array}$ & $\begin{array}{c}0.020 \\
(0.059)\end{array}$ & $\begin{array}{c}0.104 \\
(0.104)\end{array}$ & $\begin{array}{c}0.013 \\
(0.060)\end{array}$ \\
\hline Married & $\begin{array}{l}0.247^{* * *} \\
(0.045)\end{array}$ & $\begin{array}{l}0.261^{* * *} \\
(0.041)\end{array}$ & $\begin{array}{l}0.111^{* * *} \\
(0.026)\end{array}$ & $\begin{array}{l}0.263^{* * * *} \\
(0.043)\end{array}$ & $\begin{array}{l}0.095^{* * *} \\
(0.026)\end{array}$ & $\begin{array}{l}0.263^{* * * *} \\
(0.043)\end{array}$ & $\begin{array}{l}0.098^{* * *} \\
(0.026)\end{array}$ & $\begin{array}{l}0.249^{* * * *} \\
(0.043)\end{array}$ & $\begin{array}{l}0.089^{* * * *} \\
(0.026)\end{array}$ \\
\hline Has children & $\begin{array}{l}-0.059 \\
(0.046)\end{array}$ & $\begin{array}{l}-0.084^{* *} \\
(0.041)\end{array}$ & $\begin{array}{c}-0.074^{* * *} \\
(0.024)\end{array}$ & $\begin{array}{l}-0.079^{*} \\
(0.044)\end{array}$ & $\begin{array}{c}-0.068^{* * *} \\
(0.024)\end{array}$ & $\begin{array}{l}-0.078^{*} \\
(0.044)\end{array}$ & $\begin{array}{c}-0.068^{* * * *} \\
(0.024)\end{array}$ & $\begin{array}{l}-0.070 \\
(0.044)\end{array}$ & $\begin{array}{c}-0.070^{* * *} \\
(0.025)\end{array}$ \\
\hline High school Graduate & $\begin{array}{l}-0.088 \\
(0.081)\end{array}$ & $\begin{array}{c}0.108 \\
(0.075)\end{array}$ & $\begin{array}{l}0.404^{* * *} \\
(0.038)\end{array}$ & $\begin{array}{c}0.040 \\
(0.085)\end{array}$ & $\begin{array}{l}0.400^{* * *} \\
(0.038)\end{array}$ & $\begin{array}{c}0.034 \\
(0.086)\end{array}$ & $\begin{array}{l}0.399^{* * *} \\
(0.038)\end{array}$ & $\begin{array}{c}0.044 \\
(0.084)\end{array}$ & $\begin{array}{l}0.382^{* * *} \\
(0.039)\end{array}$ \\
\hline College Graduate & $\begin{array}{l}0.146^{*} \\
(0.085)\end{array}$ & $\begin{array}{l}0.384^{* * * *} \\
(0.078)\end{array}$ & $\begin{array}{l}0.585^{* * *} \\
(0.040)\end{array}$ & $\begin{array}{l}0.308^{* * * *} \\
(0.092)\end{array}$ & $\begin{array}{l}0.588^{* * * *} \\
(0.041)\end{array}$ & $\begin{array}{l}0.302^{* * * *} \\
(0.092)\end{array}$ & $\begin{array}{l}0.586^{* * *} \\
(0.041)\end{array}$ & $\begin{array}{l}0.326^{* * * *} \\
(0.091)\end{array}$ & $\begin{array}{l}0.587^{* * *} \\
(0.042)\end{array}$ \\
\hline Tenure & $\begin{array}{l}0.029^{* * * *} \\
(0.004)\end{array}$ & $\begin{array}{l}0.025^{* * *} \\
(0.004)\end{array}$ & & $\begin{array}{l}0.027^{* * * *} \\
(0.004)\end{array}$ & & $\begin{array}{l}0.027^{* * * *} \\
(0.004)\end{array}$ & & $\begin{array}{l}0.027^{* * *} \\
(0.004)\end{array}$ & \\
\hline Log(income) & $\begin{array}{l}0.076^{* * *} \\
(0.014)\end{array}$ & $\begin{array}{l}0.130^{* * * *} \\
(0.015)\end{array}$ & $\begin{array}{c}0.143^{* * *} \\
(0.013)\end{array}$ & $\begin{array}{l}0.116^{* * * *} \\
(0.017)\end{array}$ & $\begin{array}{l}0.144^{* * *} \\
(0.013)\end{array}$ & $\begin{array}{l}0.115^{* * *} \\
(0.017)\end{array}$ & $\begin{array}{l}0.144^{* * *} \\
(0.013)\end{array}$ & $\begin{array}{l}0.115^{* * *} \\
(0.017)\end{array}$ & $\begin{array}{l}0.136^{* * *} \\
(0.013)\end{array}$ \\
\hline Log(wealth) & $\begin{array}{l}0.086^{* * * *} \\
(0.010)\end{array}$ & $\begin{array}{l}0.090^{* * * *} \\
(0.009)\end{array}$ & $\begin{array}{l}0.038^{* * *} \\
(0.005)\end{array}$ & $\begin{array}{l}0.091^{* * *} \\
(0.010)\end{array}$ & $\begin{array}{l}0.036^{* * *} \\
(0.005)\end{array}$ & $\begin{array}{l}0.092^{* * * *} \\
(0.010)\end{array}$ & $\begin{array}{l}0.035^{* * *} \\
(0.005)\end{array}$ & $\begin{array}{l}0.087^{* * * *} \\
(0.010)\end{array}$ & $\begin{array}{l}0.031^{* * *} \\
(0.005)\end{array}$ \\
\hline Has a DB plan & $\begin{array}{l}0.264^{* * * *} \\
(0.083)\end{array}$ & $\begin{array}{l}-0.224^{* * *} \\
(0.088)\end{array}$ & $\begin{array}{c}-0.978^{* * *} \\
(0.030)\end{array}$ & $\begin{array}{l}-0.053 \\
(0.130)\end{array}$ & $\begin{array}{c}-0.978^{* * *} \\
(0.031)\end{array}$ & $\begin{array}{l}-0.040 \\
(0.130)\end{array}$ & $\begin{array}{c}-0.979^{* * *} \\
(0.031)\end{array}$ & $\begin{array}{l}-0.124 \\
(0.133)\end{array}$ & $\begin{array}{c}-1.039^{* * *} \\
(0.031)\end{array}$ \\
\hline $\begin{array}{l}\text { Employer provides a } \\
\text { match }\end{array}$ & $\begin{array}{l}0.580^{* * * *} \\
(0.049)\end{array}$ & $\begin{array}{l}0.502^{* * *} \\
(0.044)\end{array}$ & & $\begin{array}{l}0.552^{* * *} \\
(0.050)\end{array}$ & & $\begin{array}{l}0.553^{* * * *} \\
(0.050)\end{array}$ & & $\begin{array}{l}0.540^{* * * *} \\
(0.051)\end{array}$ & \\
\hline DC ratio & & & & & $\begin{array}{l}1.509^{* * * *} \\
(0.183)\end{array}$ & & $\begin{array}{l}1.791^{* * *} \\
(0.210)\end{array}$ & & $\begin{array}{l}1.782^{* * *} \\
(0.210)\end{array}$ \\
\hline Firm size (25-99)prop & & & & & $\begin{array}{l}2.091^{* * *} \\
(0.618)\end{array}$ & & $\begin{array}{l}1.554^{* * *} \\
(0.648)\end{array}$ & & $\begin{array}{l}1.369^{* * *} \\
(0.642)\end{array}$ \\
\hline Firm size $(100+)$ prop & & & & & $\begin{array}{l}3.162^{* * *} \\
(0.306)\end{array}$ & & $\begin{array}{l}3.085^{* * *} \\
(0.309)\end{array}$ & & $\begin{array}{l}2.912^{* * *} \\
(0.310)\end{array}$ \\
\hline Rho & & $\begin{array}{l}.584 \\
(.055)\end{array}$ & & $\begin{array}{l}.404 \\
(.113)\end{array}$ & & $\begin{array}{l}.391 \\
(.114)\end{array}$ & & $\begin{array}{l}.457 \\
(.110)\end{array}$ & \\
\hline LR test of indep eq-ns & & $\begin{array}{l}\operatorname{chi} 2(1)=63.71 \\
\text { Prob }>\text { chi2 }=0 .\end{array}$ & 000 & $\begin{array}{c}\text { chi2 }(1)=10 \\
\text { Prob }>\text { chi2 }\end{array}$ & .0015 & $\begin{array}{l}\operatorname{chi} 2(1)=9.42 \\
\text { Prob }>\text { chi2 }=0\end{array}$ & 021 & $\begin{array}{c}\operatorname{chi} 2(1)=12.58 \\
\text { Prob }>\text { chi2 }=0 .\end{array}$ & \\
\hline Exclusion restriction & no & $\mathrm{nc}$ & & & & & & & \\
\hline Attitude controls & no & nc & & & & & & & \\
\hline Industry controls & no & nc & & & & & & & \\
\hline Observations & 6475 & 187 & & & & & & & \\
\hline
\end{tabular}

Source: Authors' calculations, based on data from the 2001 panel of the SIPP.

Notes: Standard errors in brackets;*** Significant at the 1 percent level;** Significant at the 5 percent level;* Significant at the 10 percent level. 
Table 6b: 401(k) Participation Models: Marginal Effects

\begin{tabular}{|c|c|c|c|c|c|}
\hline & $\begin{array}{c}\text { (1) } \\
\text { Probit }\end{array}$ & $\begin{array}{c}\text { (2) } \\
\text { Bivariate Probit with } \\
\text { Sample Selection }\end{array}$ & $\begin{array}{c}\text { (3) } \\
\text { Bivariate Probit with } \\
\text { Sample Selection }\end{array}$ & $\begin{array}{c}\text { (4) } \\
\text { Bivariate Probit with } \\
\text { Sample Selection }\end{array}$ & $\begin{array}{c}\text { (5) } \\
\text { Bivariate Probit with } \\
\text { Sample Selection }\end{array}$ \\
\hline Female & $\begin{array}{c}-0.044^{* * * *} \\
(0.010)\end{array}$ & $\begin{array}{c}-0.073^{* * *} \\
(0.014)\end{array}$ & $\begin{array}{c}-0.072^{* * * *} \\
(0.015)\end{array}$ & $\begin{array}{c}-0.071^{* * *} \\
(0.015)\end{array}$ & $\begin{array}{c}-0.057^{* * *} \\
(0.016)\end{array}$ \\
\hline Age & $\begin{array}{l}0.025^{* * *} \\
(0.003)\end{array}$ & $\begin{array}{l}0.053^{* * *} \\
(0.005)\end{array}$ & $\begin{array}{l}0.048^{* * *} \\
(0.006)\end{array}$ & $\begin{array}{l}0.048^{* * *} \\
(0.006)\end{array}$ & $\begin{array}{l}0.049^{* * *} \\
(0.006)\end{array}$ \\
\hline$A g e^{\wedge 2}$ & $\begin{array}{c}-0.000^{* * *} \\
(0.000)\end{array}$ & $\begin{array}{c}-0.001^{* * *} \\
(0.000)\end{array}$ & $\begin{array}{c}-0.001^{* * *} \\
(0.000)\end{array}$ & $\begin{array}{c}-0.001^{* * * *} \\
(0.000)\end{array}$ & $\begin{array}{c}-0.001^{* * *} \\
(0.000)\end{array}$ \\
\hline White & $\begin{array}{c}0.039 \\
(0.024)\end{array}$ & $\begin{array}{l}0.070^{* * *} \\
(0.032)\end{array}$ & $\begin{array}{l}0.066^{* *} \\
(0.034)\end{array}$ & $\begin{array}{l}0.071^{* *} \\
(0.034)\end{array}$ & $\begin{array}{l}0.072^{* *} \\
(0.034)\end{array}$ \\
\hline Black & $\begin{array}{c}0.023 \\
(0.024)\end{array}$ & $\begin{array}{c}0.040 \\
(0.038)\end{array}$ & $\begin{array}{c}0.038 \\
(0.038)\end{array}$ & $\begin{array}{c}0.042 \\
(0.039)\end{array}$ & $\begin{array}{c}0.040 \\
(0.040)\end{array}$ \\
\hline Married & $\begin{array}{l}0.063^{* * *} \\
(0.012)\end{array}$ & $\begin{array}{l}0.104^{* * *} \\
(0.016)\end{array}$ & $\begin{array}{l}0.100^{* * * *} \\
(0.017)\end{array}$ & $\begin{array}{l}0.100^{* * * *} \\
(0.017)\end{array}$ & $\begin{array}{l}0.097^{* * *} \\
(0.017)\end{array}$ \\
\hline Has children & $\begin{array}{l}-0.014 \\
(0.012)\end{array}$ & $\begin{array}{l}-0.033^{* *} \\
(0.016)\end{array}$ & $\begin{array}{l}-0.030^{*} \\
(0.017)\end{array}$ & $\begin{array}{l}-0.030^{*} \\
(0.017)\end{array}$ & $\begin{array}{l}-0.027 \\
(0.017)\end{array}$ \\
\hline High school Graduate & $\begin{array}{l}-0.022 \\
(0.020)\end{array}$ & $\begin{array}{c}0.043 \\
(0.030)\end{array}$ & $\begin{array}{c}0.015 \\
(0.033)\end{array}$ & $\begin{array}{c}0.013 \\
(0.033)\end{array}$ & $\begin{array}{c}0.017 \\
(0.033)\end{array}$ \\
\hline College Graduate & $\begin{array}{l}0.036^{*} \\
(0.021)\end{array}$ & $\begin{array}{l}0.152^{* * *} \\
(0.031)\end{array}$ & $\begin{array}{l}0.116^{* * * *} \\
(0.037)\end{array}$ & $\begin{array}{l}0.113^{* * * *} \\
(0.037)\end{array}$ & $\begin{array}{l}0.125^{* * *} \\
(0.037)\end{array}$ \\
\hline Tenure & $\begin{array}{c}0.007^{* * *} \\
(0.001)\end{array}$ & $\begin{array}{l}0.010^{* * * *} \\
(0.001)\end{array}$ & $\begin{array}{l}0.010^{* * * *} \\
(0.001)\end{array}$ & $\begin{array}{l}0.010^{* * * *} \\
(0.001)\end{array}$ & $\begin{array}{l}0.010^{* * * *} \\
(0.001)\end{array}$ \\
\hline Log(income) & $\begin{array}{c}0.019^{* * *} \\
(0.003)\end{array}$ & $\begin{array}{l}0.052^{* * *} \\
(0.006)\end{array}$ & $\begin{array}{l}0.044^{* * * *} \\
(0.008)\end{array}$ & $\begin{array}{l}0.044^{* * * *} \\
(0.008)\end{array}$ & $\begin{array}{l}0.045^{* * *} \\
(0.007)\end{array}$ \\
\hline Log(wealth) & $\begin{array}{c}0.021^{* * *} \\
(0.002)\end{array}$ & $\begin{array}{l}0.036^{* * * *} \\
(0.004)\end{array}$ & $\begin{array}{l}0.035^{* * *} \\
(0.004)\end{array}$ & $\begin{array}{l}0.035^{* * * *} \\
(0.004)\end{array}$ & $\begin{array}{l}0.034^{* * * *} \\
(0.004)\end{array}$ \\
\hline Has a DB plan & $\begin{array}{c}0.058^{* * *} \\
(0.016)\end{array}$ & $\begin{array}{c}-0.089^{* * *} \\
(0.034)\end{array}$ & $\begin{array}{l}-0.020 \\
(0.051)\end{array}$ & $\begin{array}{l}-0.015 \\
(0.050)\end{array}$ & $\begin{array}{l}-0.049 \\
(0.054)\end{array}$ \\
\hline Employer provides a match & $\begin{array}{l}0.168^{* * * *} \\
(0.016) \\
\end{array}$ & $\begin{array}{l}0.200^{* * * *} \\
(0.017)\end{array}$ & $\begin{array}{l}0.210^{* * * *} \\
(0.018)\end{array}$ & $\begin{array}{l}0.210^{* * * *} \\
(0.018)\end{array}$ & $\begin{array}{l}0.210^{* * *} \\
(0.018)\end{array}$ \\
\hline Exclusion restriction & no & no & yes & yes & yes \\
\hline Attitude controls & no & no & no & yes & yes \\
\hline Industry controls & no & no & no & no & yes \\
\hline Observations & 6475 & 18762 & 18762 & 18762 & 18762 \\
\hline
\end{tabular}

Source: Authors' calculations, based on data from the 2001 panel of the SIPP

Notes: Marginal effects calculated at means using discrete changes for the dummy variables. Standard errors in brackets.

*** Significant at the 1 percent level.

** Significant at the 5 percent level.

* Significant at the 10 percent level. 
Table 7a: Predicted Probabilities of Participation in 401(k) if All 401(k) Plans

Provide and Employer Match, by Model Specification and Income Model Specification

\begin{tabular}{lccccc} 
& $(1)$ & $(2)$ & $(3)$ & $(4)$ & $(5)$ \\
\hline Lower Income Tercile & $64.6 \%$ & $36.1 \%$ & $45.1 \%$ & $45.6 \%$ & $41.8 \%$ \\
Middle Income Tercile & $79.2 \%$ & $55.3 \%$ & $64.4 \%$ & $65.0 \%$ & $61.7 \%$ \\
$\begin{array}{l}\text { Upper Income Tercile } \\
\begin{array}{l}\text { Participation Gap between High } \\
\text { and Low Income Terciles }\end{array}\end{array}$ & $\mathbf{8 8 . 6 \%}$ & $71.0 \%$ & $78.7 \%$ & $79.1 \%$ & $76.6 \%$ \\
& $24.0 \%$ & $34.8 \%$ & $33.6 \%$ & $33.5 \%$ & $34.8 \%$
\end{tabular}

Source: Authors' calculations, based on data from the 2001 panel of the SIPP. 
Table 7b: Predicted Probabilities of Participation in 401(k) if No 401(k) Plans Provide and Employer Match, by Model Specification and Income

\section{Model Specification}

(1)

Lower Income Tercile

Middle Income Tercile

Upper Income Tercile

Participation Gap between High

and Low Income Terciles
(2)

(3)

$\begin{array}{lllll}61.6 \% & 37.7 \% & 45.3 \% & 46.0 \% & 43.0 \%\end{array}$

$75.3 \% \quad 53.9 \% \quad 61.8 \% \quad 62.5 \% \quad 59.8 \%$

$30.5 \% \quad 32.0 \% \quad 33.9 \% \quad 34.0 \% \quad 34.1 \%$

Source: Authors' calculations, based on data from the 2001 panel of the SIPP. 